\title{
CHEMISTRY \\ AND PLANT ECOLOGY OF ZINC-RICH STREAMS IN FRANCE. 2. THE PYRÉNÉES
}

\author{
by P. J. SAY ${ }^{1}$ and B. A. WHITTON ${ }^{1}$
}

An account is given of the chemistry and phytobenthos of streams in the vicinity of two old lead mines in the Hautes-Pyrenées south of Lourdes. All of the nine sites studied had elevated levels of aqueous $\mathrm{Zn}$, and also in most cases of $\mathrm{Cd}$ and $\mathrm{Pb}$. There was some evidence that increasing levels of heavy metals led to a decreased flora, but 30 species were recorded at sites with $>10 \mathrm{mg}^{-1}$ $\mathrm{Zn}$. The most restricted flora occurred at a site with a conspicuous white precipitate, consisting largely of anglesite; here only three species were present: Schizothrix sp., Pohlia cruda, Solenostoma crenulatum.

\section{Chimie et écologie de la végétation de cours d'eau en France à fortes teneurs en zinc. 2. Les Pyrénées}

La chimie et le phytobenthos ont été étudiés dans 9 stations sur les cours d'eau près de deux mines de plomb dans les Hautes-Pyrénées. A chaque station les teneurs de $\mathrm{Zn}$ et dans la plupart des cas de $\mathrm{Cd}$ et $\mathrm{Pb}$, sont élevées. Une flore réduite s'est manifestée tandis que les teneurs des métaux lourds ont augmenté, et pourtant 30 espèces ont été trouvées dans les stations avec $>10 \mathrm{mg}^{-1} \mathrm{Zn}$. La flore la plus réduite a été trouvée à la station où il existe un précipité blanc d'anglesite; à cette station 3 espèces ont été trouvées: Schizothrix sp., Pohlia cruda, Solenostoma crenulatum.

\section{INTRODUCTION}

Within the Pyrenees, the Central Pyrenees is the richest in minerals and according to Charrin (1952), is also one of the richest areas in the whole of France. Apart from a few floristic records given by Whitton (1980), there are no accounts of stream phytobenthos in the mining areas, but Besch et al. (1972) and Backhaus (1976) have surveyed nonpolluted streams in the same region. The present paper describes the chemistry and phytobenthos of two abandoned mining areas south of Lourdes.

1. Department of Botany. University of Durham, South Road, Durham DHI 3 LE, England. 


\section{1. - METHODS}

Samples were taken from Pierrefitte Mine on 8 April, 3 June and 7 August 1977 and 15 April, 29 June and 18 September 1978. Estaing Mine is accessible only during the summer, so samples were taken on only the June and August dates. The use of $10 \mathrm{~m}$ reaches and analytical methods were the same as in the previous paper. Phytobenthos were scored on a 5-point scale on each occasion, but the data have been simplified in Table 5 to a presence/absence format. Nevertheless comments on the abundance of various species are based on the full records which are held on computer file.

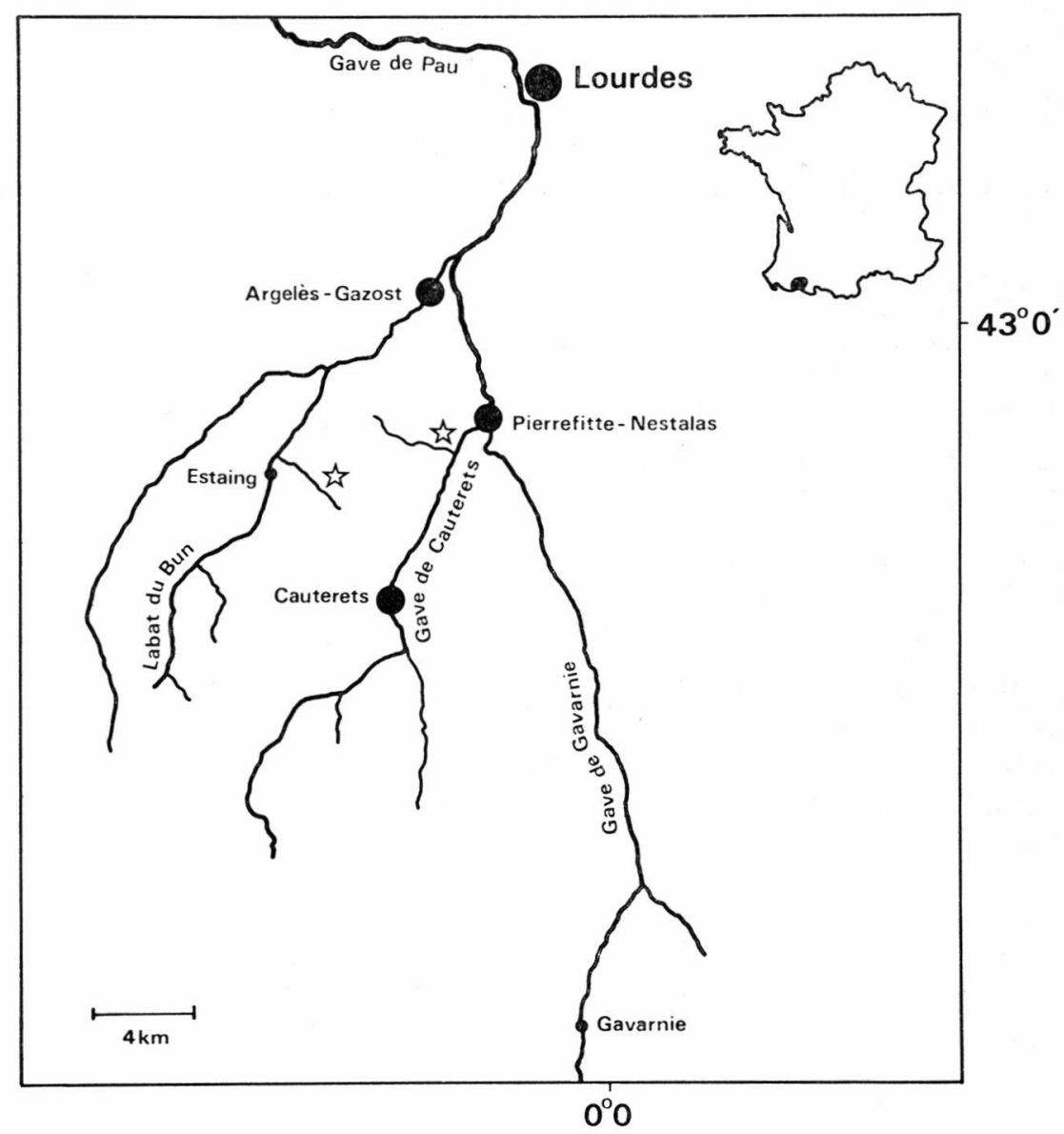

FIg. 1. - Location of Estaing and Pierrefitte Mines. 


\section{2. - ENVIRONMENTAL BACKGROUND}

The two mining areas are in tributary valleys of the Gave de Pau (fig. 1). One borders the Gave de Cauterets about $2 \mathrm{~km}$ south of Pierrefitte-Nestalas, while the other borders the Labat de Bun near Estaing.

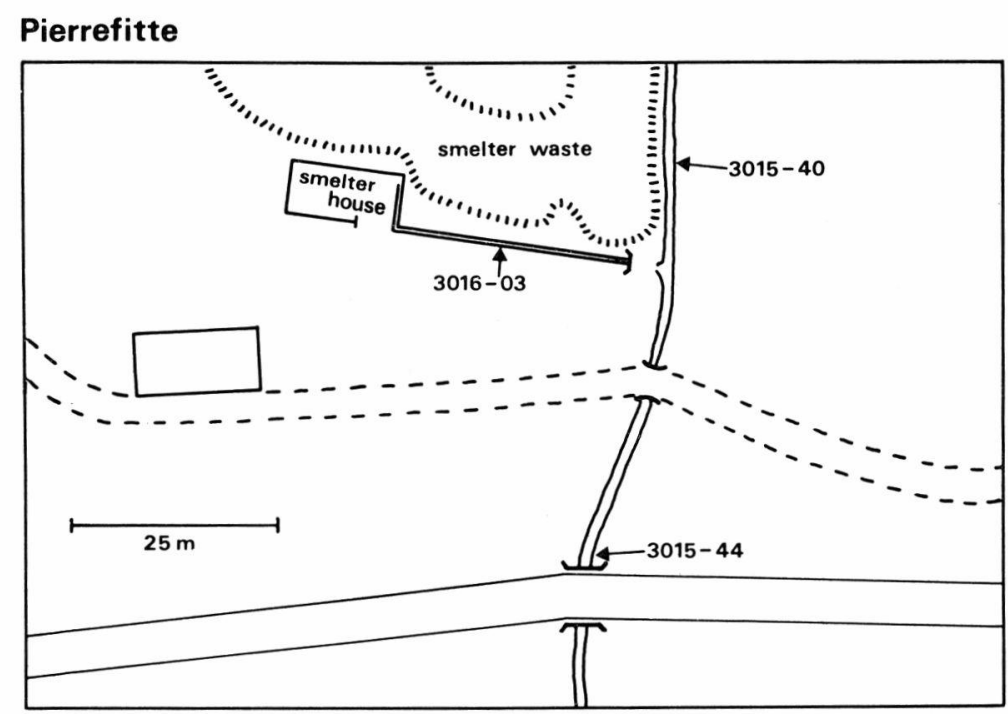

\section{Estaing}

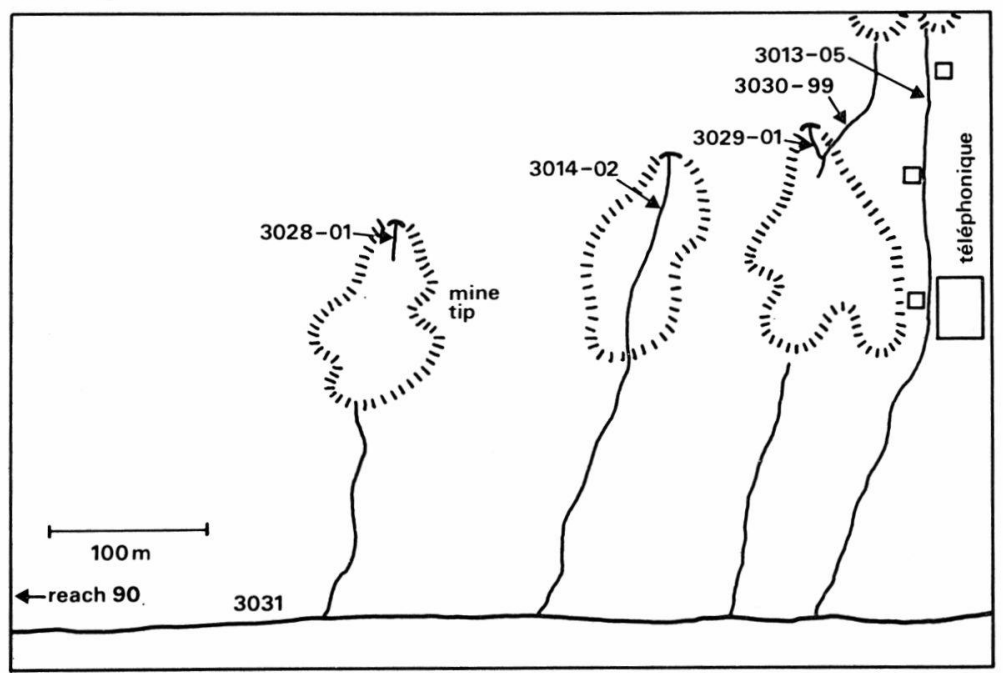

FIG. 2. - Schematic maps of streams at the two mines. 


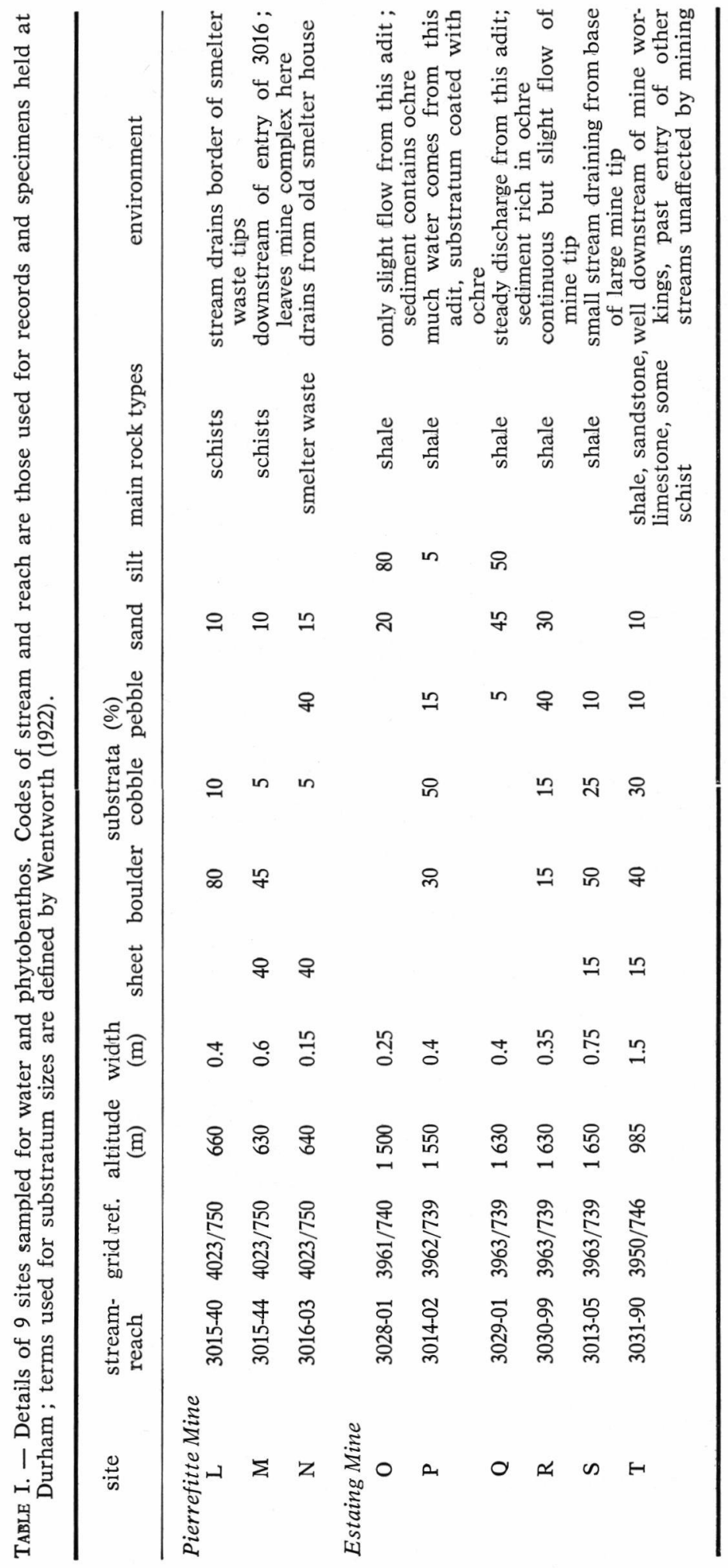




\section{1. - Pierrefitte Mine}

The mineral veins of this derelict lead mine are associated with a host rock of low to medium grade metamorphic formations, primarily schists. The main mineral is galena, with also some sphalerite, chalcopyrite and pyrite. The extensive workings extend up to $1200 \mathrm{~m}$ on the slopes of Pic d'Arraille, but study was restricted to two streams associated with the lower part of the mine complex (fig. 2). Here large tips of waste surround an old treatment plant and smelter.

\section{2. - Estaing Mine}

Although the area nearby is dominated by metamorphic rocks such as schists, the mineral veins at this derelict lead mine are associated with carbonate-rich rocks and shales. The main mineral is sphalerite

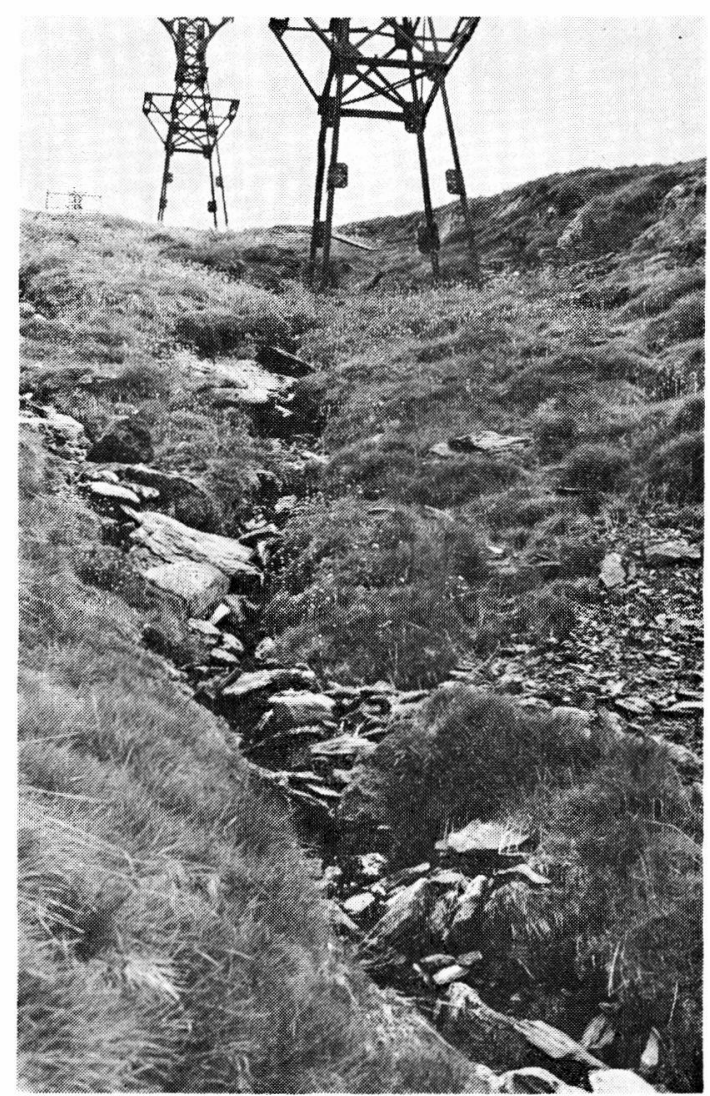

Fig. 3. - Estaing Mine : view of 3013-05; pale cover on sheets of rock is due largely to Plectonema. 


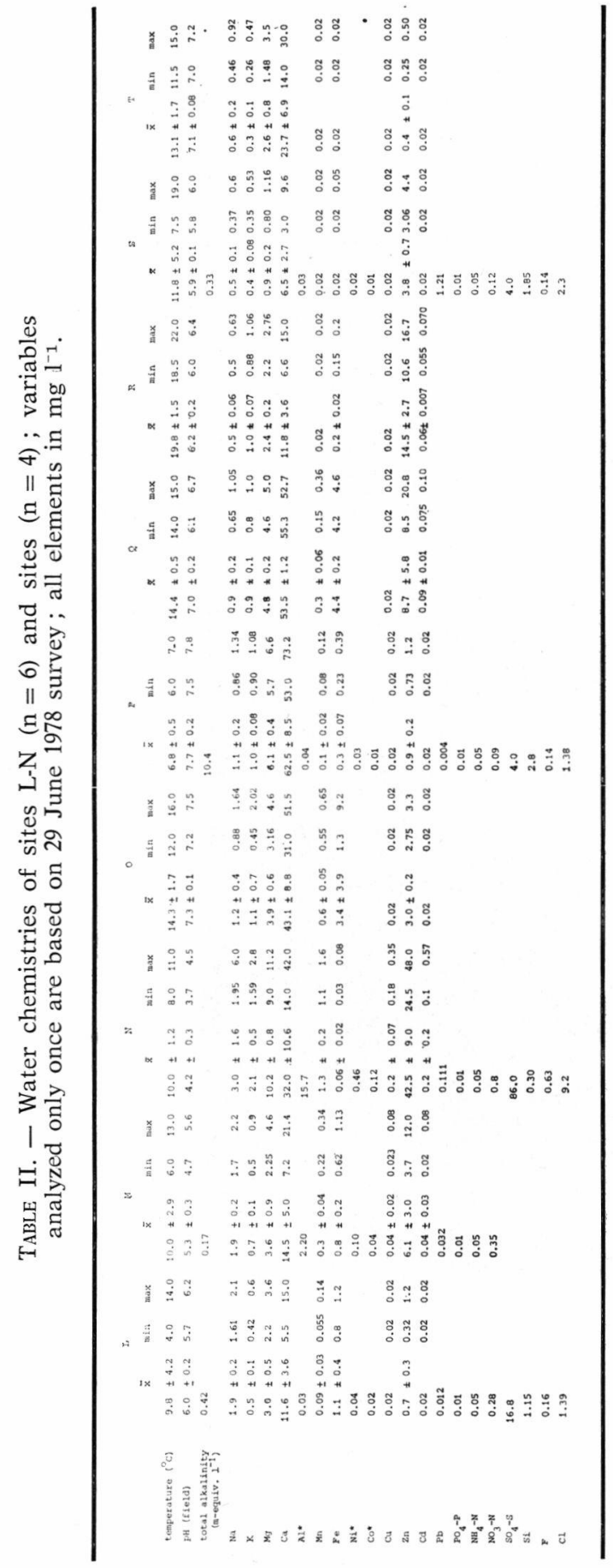

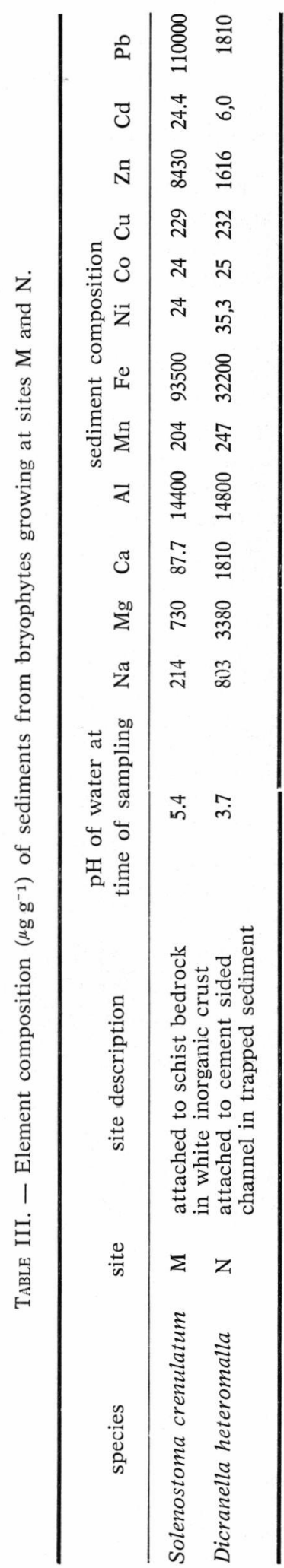


associated with some galena. The mine is situated below a peak (Puyos) on the slopes of Pic de Cabaliros at $1600 \mathrm{~m}$. There are several adits with extensive tips of waste rock and ore below their entrances. One of the small streams studied is shown in fig. 3 ; the figure illustrated by Ernst $(1974$, p. 86$)$ is taken slightly further down the same stream. (This site is called Pierrefitte Mine by Ernst (1966 and 1974).)

\section{3. - RESULTS}

\section{1. - Water chemistry}

Sites in the area of the Pierrefitte Mine had waters with low $\mathrm{pH}$ values (Table II), especially site $\mathrm{N}$, with a mean $\mathrm{pH}$ of 4.2 ; the levels of all heavy metals except $\mathrm{Pb}$ were higher than at any other site at either mine. At site L only $\mathrm{Zn}$ occurred at elevated levels, but concentrations of all metals increased after entry of stream 3016.

Streams in the area of the Estaing Mine showed a varied chemistry according to their source. Adit streams (sites O, P, Q) had a neutral to alkaline $\mathrm{pH}$ and were markedly base-rich. Streams draining from waste tips (sites $\mathrm{R}, \mathrm{S}$ ) had lower $\mathrm{pH}$ values, with low levels of total alkalinity and calcium. All of the sites had elevated levels of $\mathrm{Zn}$ and in some cases also $\mathrm{Cd}$. The highest level of $\mathrm{Pb}$ recorded anywhere was at site $\mathrm{S}$.

\section{2. - Sediments}

The composition of the sediments at sites $\mathrm{M}$ and $\mathrm{N}$ is summarized in Tables III and IV. Solenostoma crenulatum at M grew healthily. The very high levels of $\mathrm{Zn}$ and $\mathrm{Pb}$ found in the digest of this sediment (Table III) confirm the results of X-ray diffraction (Table IV), which show the sediment at this site to be a mixture dominated by anglesite, but including also the smelter waste product, zinc ferrite.

\section{3. - Plants}

The occurrence of fully submerged photosynthetic plants at the nine sites is shown in Table V. 69 species were recorded at these sites; 30 of these were recorded from sites with mean levels of $\mathrm{Zn}>10 \mathrm{mg} \mathrm{l}^{-1}$, while 20 species were recorded from the site with the highest level of rinc (site $\mathrm{N}, \mathrm{x}=42.5 \mathrm{mg}^{-1} \mathrm{Zn}$ ). The occurrence of partially submerged and bank species of bryophyte is shown in Table VI; some of these also occurred fully submerged (Table V). There were 4 liverworts and 13 mosses. 


\section{3. - DISCUSSION}

Mining in the vicinity of Pierrefitte and Estaing Mines ceased in the 1960's, but the streams draining these areas still carry very high levels of zinc, cadmium and lead. The sources of the heavy metals in streams draining the Pierrefitte Mine complex are mainly from the weathering of primary minerals such as sphalerite and galena, together with secondary minerals (anglesite, zinc ferrite, zinc ferrate) associated with the large smelter waste tips. In contrast, the metals in the streams draining the Estaing Mine workings not only come from waste tips with appreciable quantities of sphalerite and galena, but also from adits which discharge groundwaters circulating in contact with old worked mineral veins of zinc and lead.

The low $\mathrm{pH}$ of stream 3016 at site $\mathrm{N}$ is due to the oxidation of sulphide minerals in the smelter waste. The resulting acid conditions would be likely to mobilise heavy metals associated with the waste, hence producing the high levels of zinc, and, to a lesser extent, copper,

TABLE IV. - Mineral composition of sediments attached to bryophytes growing at sites $\mathrm{M}$ and $\mathrm{N}$.

$\begin{array}{lll}\text { species } & \text { site } & \begin{array}{l}\text { composition of sediment attached to bryophyte } \\ \text { mineral }\end{array}\end{array}$

Solenostoma crenulatum $\quad \mathbf{M}$ anglesite $\left(\mathrm{PbSO}_{4}\right)$ dominant mineral in sample; in the field forming a thick white crust covering the substratum; a common secondary lead mineral in the oxidised zone of lead deposits

zinc ferrite

$\left(\mathrm{ZnFe} \cdot \mathrm{O}_{4}\right)$

quartz

amphibole

chlorite

Dicranella heteromalla N $\begin{gathered}\text { muscovite } \\ \text { chlorite }\end{gathered}$ quartz second most common mineral in this sample and one often associated with remains of smelter waste

commonly associated gangue mineral with lead and zinc ores; also a constituent of some metamorphic rocks: could come from either source here

this encompasses a wide group of rock-forming silicates; probably present in this sample as a result of weathering of the schist bedrock

can occur as an alteration product of amphiboles and as a component of schists

from weathering of bedrock from weathering of bedrock from weathering of bedrock 
TABLE V. - Taxa recorded submerged at sites L-T. Totals refer to number of times (maximum of 6 for sites L-N, and 4 for sites O-T in which taxa were recorded).

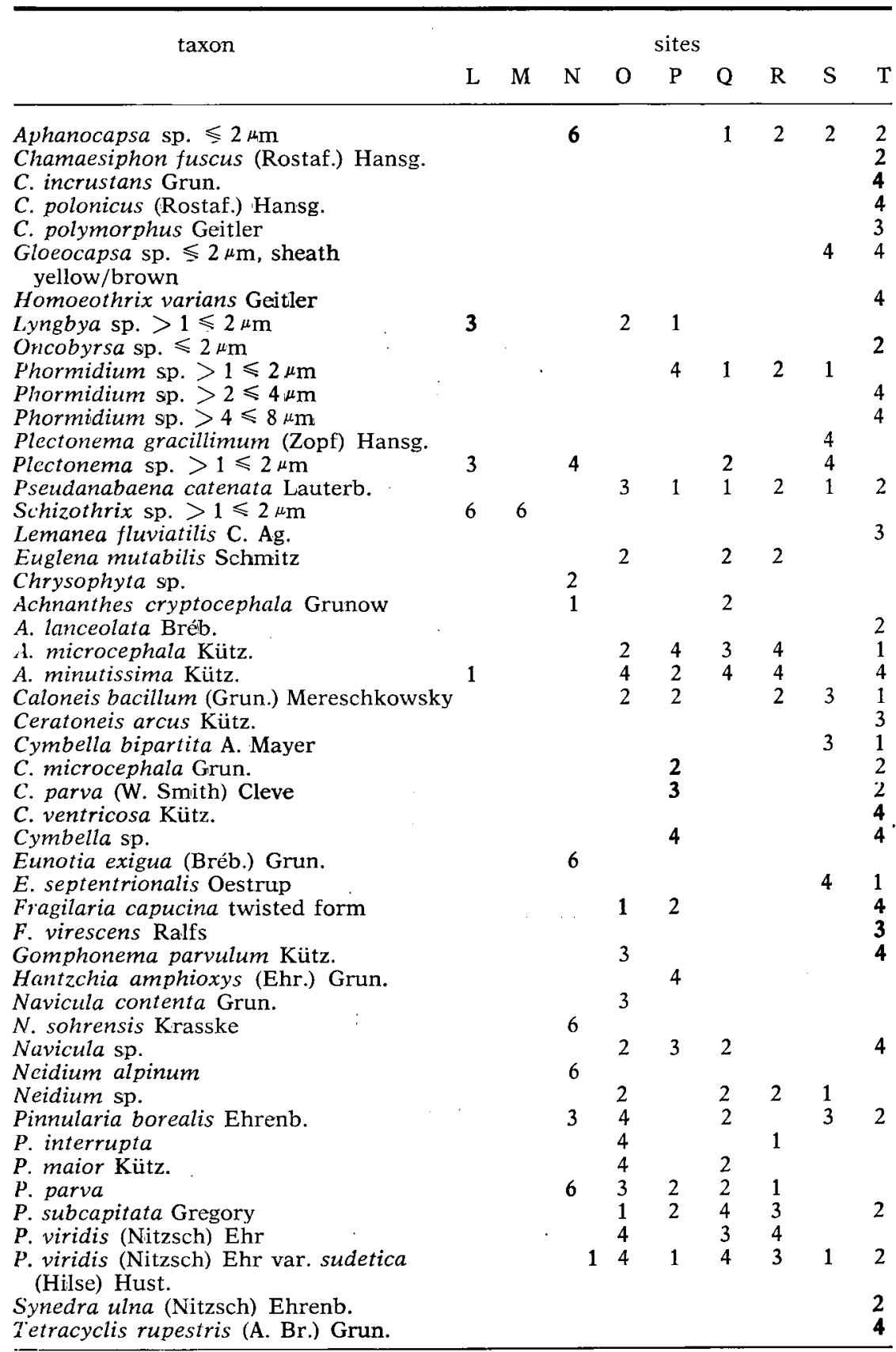


TABLE V (contd.)

\begin{tabular}{|c|c|c|c|c|c|c|c|c|c|}
\hline \multirow[t]{2}{*}{ taxon } & \multicolumn{9}{|c|}{ sites } \\
\hline & $\mathrm{L}$ & M & $\mathrm{N}$ & $\mathrm{O}$ & $P$ & Q & $\mathrm{R}$ & $\mathrm{S}$ & $\mathrm{T}$ \\
\hline Mougeotia sp. $<8 \mu \mathrm{m}$ & & & & 2 & 2 & 3 & 3 & 1 & 1 \\
\hline Mougeotia sp. $>8 \leqslant 12 \mu \mathrm{m}$ & & & 3 & 2 & & & & & \\
\hline $\begin{array}{l}\text { Mougeotia sp. }>16 \leqslant 14 \mu \mathrm{m} \\
\text { Chlamydomonas } \mathrm{sp} .(\mathrm{p} .)>8 \mu \mathrm{m} \text {, motile }\end{array}$ & & & 2 & & 4 & 2 & 2 & & 2 \\
\hline $\begin{array}{l}\text { Chlamydomonas sp. (p.) }>8 \mu \mathrm{m} \text {, motile } \\
\text { Gongrosira incrustans Schmidle }\end{array}$ & & & 2 & & & & & & 4 \\
\hline Hormidium rivulare Kütz. & & & 6 & & & 2 & 2 & 4 & 1 \\
\hline Microthamnion strictissimum Rabenh. & & & 4 & & & & & & \\
\hline Raphidonema sp. & & & 5 & & & & & & \\
\hline Stichococcus bacillaris Nägeli & & & 2 & & & & & & \\
\hline Verrucaria sp. & 3 & & 6 & & & & & 3 & 4 \\
\hline $\begin{array}{l}\text { Nardia scalaris (Schrad.) Gray } \\
\text { Solenostoma crenulatum (Sm.) Mitt. }\end{array}$ & & 6 & 6 & 4 & & & & & \\
\hline S. sphaerocarpum (Hook.) Steph. & & & & & & & & 4 & \\
\hline S. triste (Nees) K. Mull. & 6 & & & & & & & & \\
\hline $\begin{array}{l}\text { Bryum pallens } \mathrm{Sw} . \\
\text { B. weigelii Spreng. }\end{array}$ & & & & 4 & & 4 & & & \\
\hline *Dicranella heteromalla (Hedw.) & & & 6 & & & & & & \\
\hline $\begin{array}{l}\text { Pohlia cruda (Hedw.) Lindb. } \\
\text { Rhynchostegium riparioides (Hedw.) }\end{array}$ & & 6 & 6 & & & & & & \\
\hline C. Jens & & & & & & & & & 4 \\
\hline total taxa at site & 6 & 5 & 20 & 22 & 16 & 20 & 16 & 16 & 37 \\
\hline
\end{tabular}

* identified as Ditrichum cylindricum by Whitton (1980).

TABLE VI. - Bryophytes (submerged and "bank") occurring at sites L-T.

\begin{tabular}{|c|c|c|c|c|c|c|c|c|c|}
\hline \multirow[t]{2}{*}{ species } & \multicolumn{9}{|c|}{ sites } \\
\hline & $\mathrm{L}$ & M & $\mathrm{N}$ & $\mathrm{O}$ & $\mathbf{P}$ & $\mathbf{Q}$ & $\mathrm{R}$ & $\mathrm{S}$ & $\mathrm{T}$ \\
\hline $\begin{array}{l}\text { Nardia scalaris } \\
\text { Solenostoma crenulatum } \\
\text { S. sphaerocarpum } \\
\text { S. triste } \\
\text { Bryum pallens } \\
\text { B. pseudotriquetrum (Hedw.) Schwägr. } \\
\text { B. weigelii } \\
\text { Cratoneuron commutatum (Hedw.) Roth } \\
\text { C. commutatum var. falcatum (Brid.) Moenk } \\
\text { Dicranella heteromalla } \\
\text { D. varia (Hedw.) Schp. } \\
\text { Gymnostomum aeruginosum Sm. } \\
\text { Philinotis fontana (Hedw.) Brid. } \\
\text { Pohlia nutans (Hedw.) Lindb. } \\
\text { P. cruda } \\
\text { Pohlia sp. } \\
\text { Rhynchostegium riparioides }\end{array}$ & + & + & + & + & $\begin{array}{l}+ \\
+ \\
+ \\
+\end{array}$ & + & + & $\begin{array}{l}+ \\
+\end{array}$ & + \\
\hline
\end{tabular}


cadmium and lead. The conspicuous covering of anglesite over the whole bed of stream 3015 at sites $\mathrm{L}$ and, in particular, $\mathrm{M}$ is probably due simply to decreased solubility associated with a $\mathrm{pH}$ rise. There was no obvious covering of anglesite at site $\mathrm{N}$ with its lower $\mathrm{pH}$ of water and the levels of heavy metals in the sediment attached to Dicranella heteromalla at $\mathrm{N}$ were in general lower than those attached to Solenostoma crenulatum at $\mathbf{M}$.

The high levels of zinc and calcium in the water at site $\mathrm{R}$ and of zinc and lead at site $S$ are probably also related to their high mobility under slightly acid conditions. In general the adit waters which had circulated over carbonate-rich rock, especially site P, carried lower levels of zinc and other heavy metals. At these sites, and again especially at $P$, there was a conspicuous coating of ochre (hydrated oxides of iron) covering much of the substratum. Metals such as zinc are less soluble in the alkaline, base-rich waters (Hem, 1972) and might also become bound by the insoluble iron compounds.

In general there is no pronounced increase in the number of species between stream sites in the two areas as the levels of heavy metals decrease, but rather a much more obvious change in the species composition. A somewhat similar response has been reported (Say \& Whitton, 1981) from a stream draining a lead-zinc mining area in Northern England. Of the 20 species recorded at site $\mathrm{N}$ of the Estaing Mine, 9 were not found at any of the other sites. Three of these, Eunotia exigua, Hormidium rivulare and Microthamnium strictissimum, are common in highly acidic streams originating from acid mine drainages (Hargreaves, Lloyd \& Whitton, 1975 ; Whitton \& Diaz, in press); such drainages also carry high levels of heavy metals. At site $\mathrm{N}$ Hormidium rivulare was especially abundant, forming dense green tufts attached to smelter waste throughout the whole length of the stream ; this was also the dominant in the stream showing a gradient of zinc studied by Say and Whitton (1981). Four diatoms, Eunotia exigua, Neidium alpinum, Navicula sohrensis and Pinnularia parva, were also abundant or frequent at this site; the former two species were found in the study of Say and Whitton (1981) to be restricted to the highest levels of zinc.

Narrow forms of blue-green algae were frequent at two sites. Schizothrix sp. was the only alga accompanying the two bryophytes at $\mathrm{M}$, developing in close association with the anglesite. Sheets of Plectonema were conspicuous at $\mathrm{S}$. (The distinction into two genera is rather arbitrary; morphologically the forms from the two sites were quite similar.) Similar narrow forms of occasionally branched, sheathed Oscillatoriaceae are widespread in shallow zinc-rich waters (Whitton, 1980) and at Elvins Tailings in the Old Lead Belt of Missouri they cover extensive areas (Whitton, Gale \& Wixson 1981). Besides 
these blue-green algae, the zinc-rich waters of the Estaing and Pierrefitte Mines show many other similarities in species composition to the zinc-rich streams draining the Northern Pennine Orefield in England (Say, 1977 ; Say \& Whitton, 1981). Frequent species in both areas include Achnanthes minutissima, Caloneis bacillum, Pinnularia borealis, $P$. subcapitata, $P$. viridis, $P$. viridis var. sudetica, Mougeotia sp. $\leqslant 8 \mu \mathrm{m}$ and Hormidium rivulare. Bryophyte similarities are the presence of Solenostoma triste, Pohlia nutans and Pohlia sp. in seepages from the base of mine tips and that of Cratoneuron commutatum, Dicranella varia and Philonotis fontana in wet flushes produced by the base-rich waters of adits.

The presence of Solenostoma crenulatum at site $\mathbf{M}$ growing among almost pure anglesite and with high levels of aqueous zinc flowing past the plants indicates that this species can be strongly resistant to lead and zinc. Heavy metal resistance in this species has already been noted by Brown and House (1978), who found it growing on disturbed soil near a lead mine and on the spoil tip of a copper mine in SouthWest England.

The larger number of algal species at site $\mathbf{T}$ is probably at least in part due to the much lower levels of zinc and very much lower levels of other heavy metals. This stream is however larger than the others and so can presumably offer a wider range of microhabitats. Its species composition shows similarities with that of two alpine streams described by Backhaus (1976) in a region of the Pyrénées unaffected by mining and not far from the present study area. The Cyanophyta were in particular similar, with species of Chamaesiphon, such as $C$. fuscus, $C$. incrustans and $C$. polonicus, Homoeothrix varians and species of Gloeocapsa and Phormidium common to both studies.

\section{ACKNOWLEDGMENTS}

The authors acknowledge again with pleasure the many people mentioned in the previous paper who provided hospitality and have aided with analyses. They are also grateful to $B$. Jacquot for permission to sample in the Pierrefitte Mine complex.

\section{REFERENCES}

Backhaus (D.). 1976. - Beiträge zur ökologie der benthischen Algen des Hochgebirges in den Pyrenäen II. Cyanophyceen und übrige Algengruppen. Int. Rev. ges. Hydrobiol., 61 : 471-516.

Besch (W. K.), Backhaus (D.), Capblance (J.) and Lavandier (P.). 1972. - Données écologiques sur les algues benthiques de Haute Montagne dans les Pyrénées. 1. Diatomées. Annls Limnol., 8 : 103-118.

Brown (D. H.) and House (K. L.). 1978. - Evidence of a copper-tolerant ecotype of the hepatic Solenostoma crenulatum. Ann. Bot., N.S., 42 : 1383-1892. 
Charrin (V.). 1952. - Les resources minérales des Prénées. Genie Civil, 72 : 243248.

ERNST (W.). 1966. - ökologisch-soziologische Untersuchungen an Schwermetallpflanzengesellschaften Südfrankreichs und des östlichen Harzvorlandes. Flora. Abt. B., 156: 301-318.

ERNST (W.). 1974. - Schwermetallvegetation der Erde (= Geobotanica Selecta V). 194 pp. Gustav Fischer, Stuttgart.

Hargreaves (J.W.), LloYD (E. J. H.) and Whitton (B. A.). 1975. - Chemistry and vegetation of highly acidic streams. Freshwat. Biol., $5:$ 563-576.

HeM (J.D.). 1972. - Chemistry and occurrence of cadmium and zinc in surface water and groundwater. Water Resour. Res., 8 : 661-679.

SAY (P. J.). 1977. - Microbial Ecology of High Zinc Level Streams. Ph. D. Thesis, University of Durham, England.

SAY (P. J.) and WhitTon (B. A.). 1981. - Changes in flora down a stream showing a zinc gradient. Hydrobiologia, $76: 255-262$.

WeNTwORTH (C. K.). 1922. - A scale of grade and class terms for clastic sediments. J. Geol., $30: 377-392$.

Whirton (B. A.). 1980. - Zinc and plants in rivers and streams. In Nriagu J.P. (ed.) Zinc in the Environment II : Health Effects. John Wiley \& Sons, New York, Chichester, Brisbane \& Toronto.

Whitron (B. A.) and Draz (B. M.). 1981. - Influence of environmental factors on photosynthetic species composition in highly acidic waters. Verh. int. Verein. theor. angew. Limnol., 21 : 1459-1465.

Whitton (B. A.), Gale (N. L.) and Wixson (B.G.). 1981. - Chemistry and plant ecology of zinc-rich wastes dominated by blue-green algae. Hydrobiologia, 83 : 331-341. 